\title{
Bioactivity and Phytochemical Studies of Seed Extracts of Anethum graveolens Linn.
}

\author{
Jayalakshmi Basavegowda ${ }^{1, *(\mathbb{D})}$, Koteshwar Anand Rao Raveesha ${ }^{2 \mathbb{D}}$, Kestur Nagaraj Amruthesh ${ }^{3(\mathbb{D})}$ \\ 1 Post Graduate Department of Botany, Maharani's Science College for Women, Mysuru-570 005, Karnataka, India; \\ jayalakshmib74@gmail.com (J.B.); \\ 2 Department of Water \& Health, Faculty of Life Sciences, JSS Academy of Higher Education and Research, Sri \\ Shivarathreeshwara Nagara, Mysuru, Karnataka, INDIA; karaveesha@gmail.com (K.A.R.); \\ 3 Applied Plant Pathology Laboratory, Department of Studies in Botany, University of Mysore, Manasagangotri, Mysuru- \\ 570 006, Karnataka, India; dr.knamruthesh@gmail.com (K.N.A.); \\ * Correspondence: jayalakshmib74@gmail.com (J.B.);
}

Scopus Author ID 6505977311

Received: 29.05.2021; Revised: 10.07.2021; Accepted: 14.07.2021; Published: 5.09.2021

\begin{abstract}
Infectious diseases cause enormous morbidity and mortality of the population worldwide every year. The increase in the rate of infectious diseases and bacteria attaining resistance to antibiotics and side effects of some synthetic antibiotics has led to an increased interest in medicinal plants as a better and natural alternative to synthetic drugs. Antibacterial activity of solvent extracts of Anethum graveolens L. was evaluated by agar cup diffusion and disc diffusion methods against some common pathogenic bacteria, namely, Escherichia coli, Klebsiella pneumoniae, Bacillus subtilis, Bacillus cereus, Salmonella typhi, and Enterobacter aerogenes. The antioxidant capacity of different extracts of Anethum graveolens was estimated by diphenyl picryl hydrazyl (DPPH), nitric oxide (NO), and hydrogen peroxide. Solvent extracts of A. graveolens recorded a good 18-19 mm inhibition zone activity with methanol extract. The MIC of A. graveolens methanol extract was recorded in the range 125-1667 $\mu \mathrm{g} / \mathrm{ml}$ for test pathogens. The $\mathrm{IC}_{50}$ values showed that methanol extract was nearly potent to butylated hydroxyanisole (BHA) followed by ethyl acetate extracts in all the methods. Methanol extracts of $A$. graveolens possess a broad spectrum of activity against several human pathogenic and potent antioxidant properties. A natural substance obtained from plants that is a part of a daily diet, a nutritional supplement with antimicrobial and antioxidant properties, constitutes a new source of herbal drugs.
\end{abstract}

Keywords: antibacterial; Minimum Inhibitory Concentration; free radicals; antioxidants; phytochemicals.

(c) 2021 by the authors. This article is an open-access article distributed under the terms and conditions of the Creative Commons Attribution (CC BY) license (https://creativecommons.org/licenses/by/4.0/).

\section{Introduction}

According to the WHO, infectious diseases are a cause of morbidity and mortality worldwide, accounting for approximately $50 \%$ of all deaths worldwide. Although the progress made in the study of bacteria and the control of microorganisms, sporadic incidents of epidemics have emerged due to drug-resistant microbes posing an enormous threat to public health [1]. The increase in the rate of infectious diseases on the population and bacteria attaining resistance to antibiotics and side effects of some synthetic antibiotics has led to an increased interest in medicinal plants as a better and natural alternative to synthetic drugs [2].

Approximately $90 \%$ of the body's energy is generated by oxygen. Oxidation is a chemical reaction that produces free radicals. Such free radicals produced in chain reactions 
may damage cells. Generally, antioxidants play an important role in inhibiting the enzymes that are responsible for damaging healthy cells. The antioxidants with low-molecular weights can safely bind with reactive oxygen free radicals to inhibit the biochemical reaction before damaging the biomolecules. [3]. Several synthetic compounds such as butylated hydroxyanisole (BHA) and butylated hydroxytoluene (BHT) are used as antioxidants, but the use of BHA and BHT is proved to be toxic and carcinogenic [4]

Plants are known for the biosynthesis of a large array of secondary metabolites (SMs), and these metabolites form the basis for various commercial pharmaceutical drugs derived from medicinal plants. The phytoconstituents with biological activities can improve human health [5]. Plant material contains mainly the primary or secondary types of metabolites. These are also referred to as natural products. The plant chemicals having medicinal properties are largely the secondary metabolites derived bio-synthetically from primary metabolites that are not directly involved in plants' growth, development, or reproduction [6]. These secondary metabolites can be classified into several groups according to their chemical classes, such as alkaloids, terpenoids, steroids, phenols, tannins, etc. [7]

India is endowed with a rich wealth of medicinal plants, representing a valuable source of natural products for maintaining human health. A large number of medicinal plants are used in several formulations for the treatment of various diseases caused by microorganisms. Nowadays, the world has shown a great interest in curing diseases using plants/plant-based drugs [8]. In recent years, many possible natural antibacterial agents have been used for several infectious diseases of bacterial and fungal origin [9]. Several plant extracts, natural foods, Vitamin $\mathrm{C}$ and $\mathrm{E}$, beta-carotene and tocopherol, and phytochemicals such as flavonoids, isoflavones, phenolics flavones, anthocyanins, coumarins, and lignans are known to possess antioxidant properties [10]. The antimicrobial and antioxidants potential of phytochemicals and their benefits have encouraged the authors to scientifically validate the antibacterial and antioxidant potential of Anethum graveolens belonging to the family Apiaceae.

Anethum graveolens belong to the family Apiaceae and order Apiales. It is commonly known as 'Dill', which is cultivated throughout the plains in India but originated in the Mediterranean. It prefers a sandy loam soil of moderate fertility and is cultivated throughout Indian plains. It is an annual, erect, glabrous herb, 30- $90 \mathrm{~cm}$ in height, hallows finely grooved stem, striped, dark green and white with bluish spots. Leaves are compound, 2 - 3 pinnate with ultimate filiform, bluish-green, and leaf sheath surrounding the stem. Flowers are pale yellow, in a compound umbel, accrescent, terminal, large fruits oblong, dorsally compressed, 3- $4 \mathrm{~mm}$ long, 1.5- $3.0 \mathrm{~mm}$ broad, ridged narrowly, and winged having two mericarps (Figure 1). The leaves and seeds are extensively used as dietary vegetables, and essential oil is extracted from the seeds. The major constituents of the oil are carvone (30-63\%)[11]. The dill leaves are used as a seasoning for soups, sauces, and pickles and used for their carminative and preservative properties [12]. The nutritional composition of A. graveolens seed is given in Table 1 [13].

Table 1.The nutritional composition of A. graveolens seeds.

\begin{tabular}{l|l|l|l} 
Constituents & \multicolumn{1}{|c|}{$\begin{array}{c}\text { Approximate } \\
\text { composition }\end{array}$} & \multicolumn{1}{c}{ Constituents } & \multicolumn{1}{c}{$\begin{array}{c}\text { Approximate } \\
\text { composition }\end{array}$} \\
\hline Moisture & $11.3 \%$ & Calcium & $498.9 \mathrm{mg} / 100 \mathrm{~g}$ \\
\hline Crude Protein & $21.9 \%$ & Iron & $56.3 \mathrm{mg} / 100 \mathrm{~g}$ \\
\hline Fat & $2.4 \%$ & Magnesium & $196.5 \mathrm{mg} / 100 \mathrm{~g}$ \\
\hline Carbohydrates & $31.7 \%$ & Potassium & $892.1 \mathrm{mg} / 100 \mathrm{~g}$ \\
\hline Crude fibre & $5.9 \%$ & Sodium & $30.2 \mathrm{mg} / 100 \mathrm{~g}$ \\
\hline Ash & $10 \%$ & Chromium & $0.12 \mathrm{mg} / 100 \mathrm{~g}$
\end{tabular}




\begin{tabular}{l|l|l|l}
\multicolumn{1}{c|}{ Constituents } & \multicolumn{1}{|c|}{$\begin{array}{c}\text { Approximate } \\
\text { composition }\end{array}$} & \multicolumn{1}{c}{ Constituents } & $\begin{array}{c}\text { Approximate } \\
\text { composition }\end{array}$ \\
\hline Oleic acid & $31.2 \mathrm{mg} / \mathrm{ml}$ & Titanium & $0.008 \mathrm{mg} / 100 \mathrm{~g}$ \\
\hline Linoleic acid & $9.2 \mathrm{mg} / \mathrm{ml}$ & Molybdenum & $0.015 \mathrm{mg} / 100 \mathrm{~g}$ \\
\hline Linolenic acid & $0.6 \mathrm{mg} / 100 \mathrm{~g}$ & Vitamin $\mathrm{C}$ & $121.4 \mathrm{mg} / 100 \mathrm{~g}$
\end{tabular}

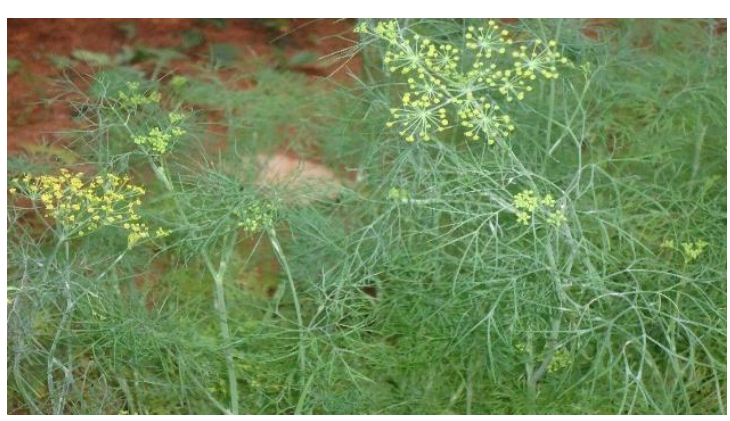

A

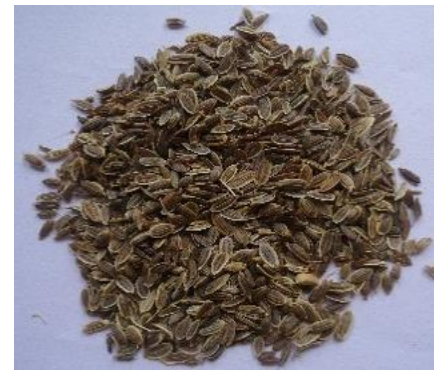

B

Figure 1. (A) Anethum graveolens plant; (B) Anethum graveolens seeds.

\section{Materials and Method}

\subsection{Plant material.}

Healthy and clean seeds Anethum graveolens of were collected from Mysuru, Karnataka, and used to prepare different solvent extracts.

\subsection{Preparation of extracts}

Healthy seeds were cleaned thoroughly, shade dried, and powdered with the help of a warning blender. $50 \mathrm{~g}$ of the powder was filled in a thimble and extracted successively with petroleum ether, chloroform, ethyl acetate, and methanol in a soxhlet extractor for $48 \mathrm{~h}$. The extracts were concentrated using a rotary flash evaporator and preserved at $5{ }^{\circ} \mathrm{C}$ in an airtight bottle until further use. All the extracts were tested for antibacterial and antioxidant activity.

\subsection{Human pathogenic bacteria.}

Authentic cultures of human pathogenic bacteria viz., Bacillus cereus (B. cereus) (MTCC 1272), Bacillus subtilis (B. subtilis) (MTCC 121), Escherichia coli (E. coli) (MTCC 7410), Enterobacter aerogens (Ent. aerogens) (MTCC 7325), Klebsiella pneumoniae (Klb. pneumoniae) (MTCC 7407), Salmonella typhi (S. typhi) (MTCC 733) and Staphylococcus aureus (Staph. aureus) (MTCC 7443) served as test bacteria were obtained from Microbial Type Culture Collections (MTCC), Chandigarh, India.

\subsection{Antibacterial activity.}

\subsubsection{Agar cup diffusion assay.}

The antibacterial activity of solvent extracts was determined by agar cup diffusion [14] and disc diffusion methods [15]. Cups were made in plates containing $20 \mathrm{ml}$ of nutrient agar media using sterile cork borer $(6 \mathrm{~mm})$, and inoculum containing $10^{6} \mathrm{CFU} / \mathrm{ml}$ of bacteria were spread uniformly over the solid media with a sterile swab moistened with the bacterial suspension. The solvent extracts were reconstituted respectively in sterile distilled water and methanol to a $100 \mathrm{mg} / \mathrm{ml}$ concentration. Solvent extracts of $100 \mu \mathrm{l}$ were placed in the cups made in the inoculated plates. Also, $100 \mu \mathrm{l}$ of sterilized distilled water and methanol were placed in the cups separately, which served as a negative control, and $100 \mu 1$ of antibiotic- 
containing $20 \mu \mathrm{g}$ streptomycin (streptomycin sulfate IP, $200 \mu \mathrm{g} / \mathrm{ml}$ ) served as a positive control. The plates were incubated for $24 \mathrm{~h}$ at $37^{\circ} \mathrm{C}$, and the zone of inhibition, if any around the cups, were measured in $\mathrm{mm}$. For each treatment, four replicates were maintained and repeated twice.

\subsubsection{Disc diffusion assay.}

The disc diffusion method was carried out according to NCCLS protocol. $100 \mu 1$ aqueous and solvent extracts were loaded to sterile discs of $6 \mathrm{~mm}$ and placed on inoculated nutrient agar in the Petri plates. Also, sterile discs loaded with $100 \mu \mathrm{l}$ of sterilized distilled water and methanol served as a negative control. Antibiotic disc of streptomycin $(20 \mu \mathrm{g})$ (streptomycin sulfate IP) served as a positive control. The plates were incubated for $24 \mathrm{~h}$ at 37 ${ }^{\circ} \mathrm{C}$, and zones of inhibition, if any around the discs, were measured in $\mathrm{mm}$. For each treatment, four replicates were maintained and repeated twice.

\subsubsection{Minimum inhibitory concentration (MIC).}

The MIC was determined in 96 well flat bottom microtiter plates based on microdilution assay, an automated turbidometric and colorimetric method described by Das [16]. Inoculum of the test bacteria was prepared from $24 \mathrm{~h}$ old bacterial cultures in sterile/saline water, and turbidity of the suspension was adjusted to $0.5 \mathrm{Mc}$ Farland.

The crude extracts of methanol, ethyl acetate, and chloroform were diluted to the concentration of $100 \mathrm{mg} / \mathrm{ml}$, which served as stock solution. The 96 well plates were filled with $200 \mu \mathrm{l}$ of nutrient broth and $100 \mu \mathrm{l}$ of the extract to the first well. A two-fold serial dilution was made along the rows, and final concentrations were 5 to $0.019 \mathrm{mg} / \mathrm{ml}$. A $10 \mu \mathrm{l}$ inoculum of each test bacteria was added to each well.

The wells containing nutrient broth with inoculum and solvent served as a negative control. The plates were incubated at $37^{\circ} \mathrm{C}$ for $24 \mathrm{~h}$, and the optical density was measured at $620 \mathrm{~nm}$ using a microplate reader (LT4000, LABTECH Instruments, UK). The lowest concentration that inhibited the visible growth of the bacteria was recorded as the MIC based on the optical density.

The MIC was also confirmed by adding $10 \mu \mathrm{l}$ of TTC (2, 3, 5-triphenyl tetrazolium chloride, Sigma) dissolved in sterile distilled water (TTC $2 \mathrm{mg} / \mathrm{ml}$ ) to each well and incubated at $37{ }^{\circ} \mathrm{C}$ for $30 \mathrm{~min}$ in the dark[17]. Viable organisms reduced the dye to a pink color compound. The lowest concentration at which the color change occurred was taken as the MIC. All MIC tests were repeated thrice.

\subsection{Antioxidant assay.}

The antioxidant capacity of different extracts of Anethum graveolens was estimated by diphenyl picryl hydrazyl (DPPH), nitric oxide (NO), and hydrogen peroxide scavenging methods.

\subsubsection{DPPH radical scavenging assay.}

The free radical-scavenging activity of the different extracts was measured in terms of hydrogen donating or radical scavenging ability using stable radical DPPH as described by the Blois method [18]. A volume of $1 \mathrm{ml}$ dimethyl sulfoxide (DMSO) was used to dissolve 0.001 $\mathrm{g}$ of the studied extracts for the preparation of stock solutions. Variable concentrations such as 
$20,40,60,80$, and $100 \mu \mathrm{g}$ of the above stock solution were diluted to $2 \mathrm{ml}$ in methanol. A volume of $1 \mathrm{ml}$ methanolic solution of DPPH $(0.1 \mathrm{mmol})$ was added to each of the test solutions. Thoroughly shaken the above mixture and recorded the absorbance of each test solution at $517 \mathrm{~nm}$ after $30 \mathrm{~min}$ incubation time. A triplicate measurement was made and presented as SD \pm mean. Ascorbic acid (AA) and DMSO were used as the standard and negative control, respectively. The capacity of the extracts to scavenge the DPPH radical was calculated using the following equation:

\section{DPPH scavenging effect $(\%)=\left[\left(\mathrm{A}_{\mathrm{c}}-\mathrm{A}_{\mathrm{b}}\right) / \mathrm{A}_{\mathrm{c}} \times 100\right]$}

where, $A_{c}$ is the absorbance of the negative control, i.e., without sample; $A_{b}$ is the absorbance of the sample.

\subsubsection{Hydroxyl radical scavenging assay.}

The hydrogen peroxide scavenges activity of these compounds was assayed according to the report by Ruch et al. [19]. The Fenton reaction system was used to generate hydroxyl radical in an aqueous media. DMSO $(1 \mathrm{ml})$ solvent was used to prepare the studied extract solution. A volume of $5 \mathrm{ml}$ assay mixture was prepared using the reagents mentioned below: Transfer different volumes of the extract such as 4,8,12,16, and $20 \mu 1$ into a series of flasks containing Safranin $(11.4 \mu \mathrm{mol})$, EDTA-Fe(II) $(40 \mu \mathrm{mol}), \mathrm{H}_{2} \mathrm{O}_{2}(1.76 \mu \mathrm{mol})$ and diluted to $5 \mathrm{ml}$ with phosphate buffer $(0.067 \mathrm{~mol}, \mathrm{pH} 7.4)$. The absorbance of the formed species was recorded at $520 \mathrm{~nm}$ after incubation $\left(37^{\circ} \mathrm{C}\right)$ period of $30 \mathrm{~min}$. Triplicate measurement was made for each using BHA (butylated hydroxyanisole) as a standard, and the values are presented $\mathrm{SD} \pm$ mean. The scavenging capacity of $\mathrm{OH} \cdot$ was determined by employing the below formula:

Suppression capacity $(\%)=\left[\left(\mathrm{A}_{\mathrm{o}}-\mathrm{A}_{\mathrm{i}}\right) / \mathrm{A}_{\mathrm{o}} \times 100\right]$

where $A_{0}$ and $A_{\mathrm{i}}$ are the absorbance of the control and test compound, respectively.

\subsubsection{Nitric oxide scavenging assay.}

Griess reagent comprises $1 \%$ sulphanilamide, $2 \%$ phosphoric acid, and $0.1 \%$ naphthyl ethylenediamine dihydrochloride.

Test of nitric oxide radical scavenging capacity was determined according to the method of Green et al. [20]. The assay is based on nitric oxide (NO) generation from sodium nitroprusside (SNP), and the same was reacted with naphthyl ethylenediamine dihydrochloride in the presence of sulphanilic acid. At physiological $\mathrm{pH}$, the generated nitric oxide from nitroprusside was reacted with oxygen to produce nitrite ion, which can be measured using the cited reagent. In phosphate buffer $(\mathrm{pH} 7.4)$, nitroprusside was mixed with different extract concentrations $\left(20,40,60,80\right.$ and $100 \mu \mathrm{g}$ ). After incubating (at $25^{\circ} \mathrm{C}$ for $150 \mathrm{~min}$ ) the mixture, it was treated with a $1.5 \mathrm{ml}$ Griess reagent volume. At room temperature, again, it was incubated for $30 \mathrm{~min}$ and diluted with buffer solution $(4 \mathrm{ml})$. The absorbance of the formed purple azo dye was recorded at $546 \mathrm{~nm}$ against the reagent blank. Triplicate measurement was made for each with the use of ascorbic acid as a standard, and the values are presented SD \pm mean. The following formula was used to calculate the percentage radical scavenging effect.

Nitric oxide scavenging effect $(\%)=\left[\left(\mathrm{A}_{\mathrm{c}}-\mathrm{A}_{\mathrm{t}}\right) / \mathrm{A}_{\mathrm{c}} \times 100\right]$

$\mathrm{A}_{\mathrm{c}}=$ absorbance of control

$A_{t}=$ absorbance in the presence of the sample of extract 


\subsection{Phytochemical analysis.}

Phytochemical analysis of aqueous and solvent extracts was carried out to detect secondary metabolites by adopting the procedure reported by Harborne [21]. The results are tabulated and discussed.

\subsection{Statistical analysis}

Statistical calculations were carried out using one-way ANOVA (analysis of variance). The significance of the differences between means was calculated using Tukey's multiple range test under the significance level of $P<0.05$.

\section{Results}

\subsection{Antibacterial activity of different solvent extracts of A. graveolens against human} pathogens.

Solvent extracts of A. graveolens recorded a good activity (Figure 2), while chloroform extract had the least activity by cup diffusion method (Table 2). Among the test bacteria $B$. cereus, Ent. aerogenes, Staph. aureus, B. subtilis, Klb. pneumoniae and S. typhi recorded a good activity of 18-19 mm inhibition zone with methanol extract, which was slightly less than the standard antibiotics streptomycin and gentamicin, indicating the efficacy of this extract. Antibacterial activity of $A$. graveolens by disc diffusion method was similar to that of cup method. Methanol extract showed maximum activity in the range $17-19.50 \mathrm{~mm}$, followed by ethyl acetate $(10-16.25 \mathrm{~mm})$ and petroleum ether $(7-13.5 \mathrm{~mm})$, while chloroform extract recorded a negligible activity (Table 3 ). The MIC of $A$. graveolens methanol extracts was recorded in the range $125-1667 \mu \mathrm{g} / \mathrm{ml}$ for human pathogens.(Table 4).

Table 2. Zone of inhibition of $A$. graveolens extracts and antibiotics against human pathogenic bacteria by agar cup diffusion method (in $\mathrm{mm}$ ).

\begin{tabular}{|c|c|c|c|c|c|c|c|}
\hline Bacteria & $\begin{array}{l}\text { Solvent } \\
\text { control }\end{array}$ & Pet. Ether & Chloroform & Ethyl acetate & Methanol & Streptomycin & Gentamycin \\
\hline B. cereus & 0.00 & $13.50 \pm 0.64^{\mathrm{bc}}$ & $12.25 \pm 0.25^{\mathrm{ab}}$ & $17.25 \pm 0.47^{\mathrm{b}}$ & $19.50 \pm 0.64^{\mathrm{a}}$ & $21.00 \pm 0.40^{\mathrm{bc}}$ & $24.30 \pm 0.33^{\mathrm{b}}$ \\
\hline B. subtilis & 0.00 & $12.00 \pm 0.40^{\mathrm{cd}}$ & $09.00 \pm 0.40^{\mathrm{d}}$ & $16.25 \pm 0.25^{\mathrm{a}}$ & $18.25 \pm 0.25^{\mathrm{a}}$ & $20.75 \pm 0.47^{\mathrm{bc}}$ & $29.30 \pm 0.88^{\mathrm{a}}$ \\
\hline E. coli & 0.00 & $13.75 \pm 0.25^{\mathrm{b}}$ & $09.25 \pm 0.47^{\mathrm{cd}}$ & $11.50 \pm 0.28^{a}$ & $14.50 \pm 0.28^{\mathrm{b}}$ & $23.75 \pm 0.47^{a}$ & $22.00 \pm 0.57^{b}$ \\
\hline Ent. aerogens & 0.00 & $15.75 \pm 0.25^{\mathrm{a}}$ & $10.75 \pm 0.25^{\mathrm{bc}}$ & $14.75 \pm 0.25^{\mathrm{a}}$ & $19.75 \pm 0.62^{\mathrm{a}}$ & $21.25 \pm 0.62^{\mathrm{bc}}$ & $23.60 \pm 0.88^{b}$ \\
\hline $\begin{array}{c}\text { Kleb. } \\
\text { pneumoniae }\end{array}$ & 0.00 & $13.50 \pm 0.28^{\mathrm{bc}}$ & $11.75 \pm 0.25^{\mathrm{ab}}$ & $14.75 \pm 0.28^{a}$ & $18.25 \pm 0.25^{\mathrm{a}}$ & $19.75 \pm 0.62^{c}$ & $22.60 \pm 0.33^{\mathrm{b}}$ \\
\hline Salm. typhi & 0.00 & $11.75 \pm 0.25^{\mathrm{d}}$ & $12.75 \pm 0.25^{\mathrm{a}}$ & $16.25 \pm 0.25^{\mathrm{a}}$ & $18.75 \pm 0.25^{\mathrm{a}}$ & $22.50 \pm 0.28^{\mathrm{ab}}$ & $23.60 \pm 0.66^{\mathrm{b}}$ \\
\hline Staph. aureus & 0.00 & $13.75 \pm 0.25^{\mathrm{b}}$ & $08.75 \pm 0.47^{\mathrm{d}}$ & $15.25 \pm 0.25^{\mathrm{a}}$ & $19.50 \pm 0.28^{\mathrm{a}}$ & $19.25 \pm 0.47^{c}$ & $30.30 \pm 0.33^{\mathrm{a}}$ \\
\hline
\end{tabular}

significantly when subjected to Tukey's HSD $(\mathrm{P}<0.05)$.

Table 3. Zone of inhibition of $A$. graveolens extracts and antibiotics against human pathogenic bacteria by disc diffusion method (in $\mathrm{mm}$ ).

\begin{tabular}{|c|c|c|c|c|c|c|c|}
\hline Bacteria & $\begin{array}{l}\text { Solvent } \\
\text { control }\end{array}$ & Pet. Ether & Chloroform & Ethyl acetate & Methanol & Streptomycin & Gentamycin \\
\hline B. cereus & 0.00 & $13.50 \pm 0.47^{\mathrm{a}}$ & $08.50 \pm 0.50^{\mathrm{b}}$ & $16.25 \pm 0.25^{\mathrm{a}}$ & $17.25 \pm 1.74^{\mathrm{ab}}$ & $19.66 \pm 0.33^{\mathrm{bc}}$ & $23.75 \pm 0.47^{\mathrm{bc}}$ \\
\hline B. subtilis & 0.00 & $11.50 \pm 0.50^{\mathrm{ab}}$ & $08.25 \pm 0.25^{b}$ & $14.25 \pm 0.47^{\mathrm{b}}$ & $18.25 \pm 0.25^{\mathrm{a}}$ & $17.30 \pm 0.33^{\mathrm{d}}$ & $28.50 \pm 0.50^{\mathrm{a}}$ \\
\hline E. coli & 0.00 & $11.00 \pm 0.57^{\mathrm{ab}}$ & $07.50 \pm 0.28^{\mathrm{b}}$ & $10.75 \pm 0.25^{\mathrm{a}}$ & $14.50 \pm 0.28^{\mathrm{b}}$ & $23.30 \pm 0.33^{\mathrm{a}}$ & $22.75 \pm 0.47^{b c}$ \\
\hline Ent. aerogens & 0.00 & $11.75 \pm 0.25^{\mathrm{ab}}$ & $09.25 \pm 0.47^{\mathrm{ab}}$ & $13.50 \pm 0.28^{\mathrm{b}}$ & $19.75 \pm 0.62^{\mathrm{a}}$ & $21.30 \pm 0.33^{\mathrm{b}}$ & $22.25 \pm 0.47^{\mathrm{c}}$ \\
\hline $\begin{array}{c}\text { Kleb. } \\
\text { pneumoniae }\end{array}$ & 0.00 & $10.75 \pm 0.25^{\mathrm{abc}}$ & $08.75 \pm 0.47^{\mathrm{ab}}$ & $16.25 \pm 0.25^{a}$ & $18.25 \pm 0.25^{\mathrm{a}}$ & $19.00 \pm 0.57^{\mathrm{cd}}$ & $24.75 \pm 0.25^{b}$ \\
\hline Salm. typhi & 0.00 & $07.00 \pm 0.25^{\mathrm{c}}$ & $10.50 \pm 0.25^{\mathrm{a}}$ & $14.75 \pm 0.47^{\mathrm{ab}}$ & $18.75 \pm 0.25^{a}$ & $20.30 \pm 0.33^{b c}$ & $22.25 \pm 0.47^{c}$ \\
\hline
\end{tabular}




\begin{tabular}{|c|c|c|c|c|c|c|c|}
\hline Bacteria & $\begin{array}{c}\text { Solvent } \\
\text { control }\end{array}$ & Pet. Ether & Chloroform & Ethyl acetate & Methanol & Streptomycin & Gentamycin \\
\hline Staph. aureus & 0.00 & $09.25 \pm 0.25^{b c}$ & $08.50 \pm 0.28^{\mathrm{b}}$ & $13.75 \pm 0.25^{\mathrm{b}}$ & $19.50 \pm 0.28^{\mathrm{a}}$ & $17.60 \pm 0.33^{\mathrm{d}}$ & $23.00 \pm 0.40^{\mathrm{bc}}$ \\
\hline
\end{tabular}

Values are means of four independent replicates. Figures followed by different letters in columns differ significantly when subjected to Tukey's HSD $(\mathrm{P}<0.05)$.

Table 4. Minimum Inhibitory Concentration of Methanol extract against human pathogenic bacteria (in $\mu \mathrm{g} / \mathrm{ml}$ ).

\begin{tabular}{l|c|c|c|c|c|c|c|}
\multicolumn{1}{c}{$\begin{array}{l}\text { Plant } \\
\text { A. graveolens }\end{array}$} & $\begin{array}{l}\text { B. subtilis } \\
\text { cereus }\end{array}$ & E. coli & $\begin{array}{l}\text { Ent. } \\
\text { aerogens }\end{array}$ & $\begin{array}{l}\text { Kleb. } \\
\text { pneumoniae }\end{array}$ & $\begin{array}{l}\text { Salm. } \\
\text { typhi }\end{array}$ & $\begin{array}{l}\text { Staph. } \\
\text { aureus }\end{array}$ \\
\hline Streptomycine & 1040 & 1667 & 1250 & 625 & 833 & 1660 & 125 \\
\hline Gentamicin & 1.05 & 25 & 12.5 & 6.25 & 12.5 & 12.5 & 6.25 \\
\hline
\end{tabular}

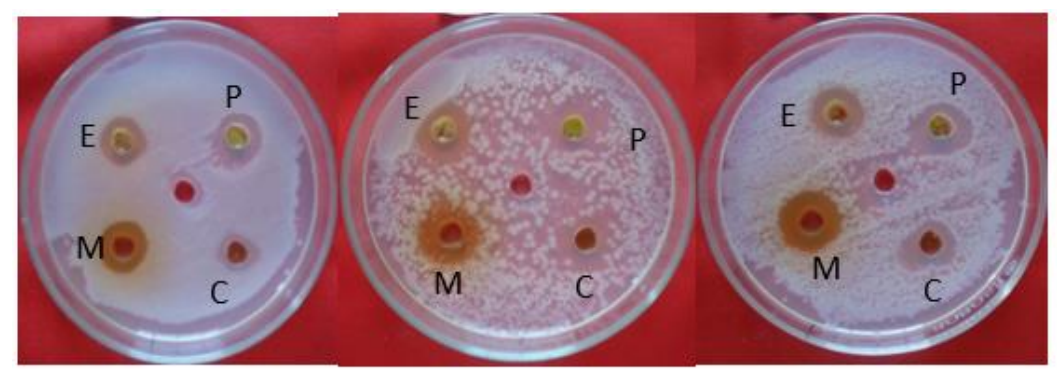

Ent. aerogens
B. subtilis

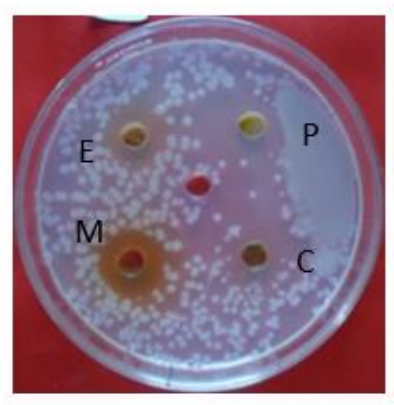

S. typhi

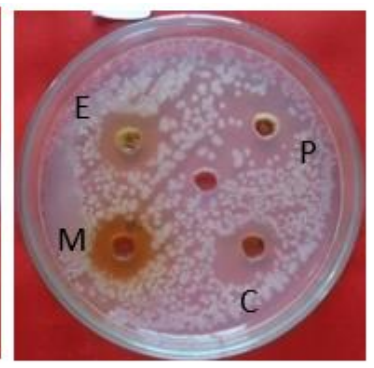

B. cereus

Figure 2. Antibacterial activity of different solvent extracts of $A$. graveolens against human pathogenic test bacteria by Cup diffusion method. Extracts of: P- Petroleum ether, C- Chloroform, E- Ethyl acetate, M-

Methanol.

\subsection{Antioxidant activity of A. graveolens.}

DPPH radical scavenging assay of A. graveolens revealed that all the solvent extracts recorded a better scavenging ability than the standard ascorbic acid. The methanol extract of the plant recorded least value of $19 \mu \mathrm{g} / \mathrm{ml}$ followed by ethyl acetate $(21 \mu \mathrm{g} / \mathrm{ml})$, petroleum ether $(24 \mu \mathrm{g} / \mathrm{ml})$ and chloroform $(25 \mu \mathrm{g} / \mathrm{ml})$ extracts. All the extracts of the plant possessed a good scavenging ability when compared to the standard ascorbic acid. $\mathrm{IC}_{50}$ values of different extracts of $A$. graveolens by hydroxyl radical scavenging exhibited efficiency in the order of BHA > methanol > ethyl acetate > chloroform > petroleum ether (Table 5). The $\mathrm{IC}_{50}$ values showed that methanol extract was nearly potent to BHA. The efficacy of the extract in scavenging nitric oxide was good in methanol and ethyl acetate extracts expressed as $\mathrm{IC}_{50}$ values and compared with the standards. 
Table 5. The $\mathrm{IC}_{50}$ values of DPPH radical, hydrogen peroxide, and nitric oxide radical scavenging by different extracts of $A$. graveolens.

\begin{tabular}{c|c|c|c}
\multirow{2}{*}{ Solvent extract } & \multicolumn{3}{|c}{$\mathbf{I C}_{\mathbf{5 0}}(\boldsymbol{\mu g} / \mathbf{~ m l})$} \\
\cline { 2 - 4 } & $\mathbf{D P P H}$ & $\mathbf{H}_{\mathbf{2}} \mathbf{O}_{\mathbf{2}}$ & Nitric oxide \\
\hline Petroleum ether & $24 \pm 0.33$ & $34 \pm 0.72$ & $48 \pm 0.31$ \\
\hline Chloroform & $25 \pm 0.12$ & $38 \pm 0.55$ & $41 \pm 0.41$ \\
\hline Ethyl Acetate & $21 \pm 0.55$ & $32 \pm 0.32$ & $40 \pm 0.24$ \\
\hline Methanol & $19 \pm 0.94$ & $28 \pm 0.36$ & $36 \pm 0.64$ \\
\hline AA & $25 \pm 0.34$ & --- & $23 \pm 0.21$ \\
\hline BHA & --- & $22 \pm 0.08$ & -- \\
\multicolumn{2}{c}{ Values are mean of three independent replicates \pm Standard Deviation. }
\end{tabular}

The antioxidant efficacy of all the extracts of A. graveolens by DPPH, hydrogen peroxide, and nitric oxide radical scavenging methods increases with the increase in concentration. The data are depicted in Figures 3, 4, and 5, respectively.

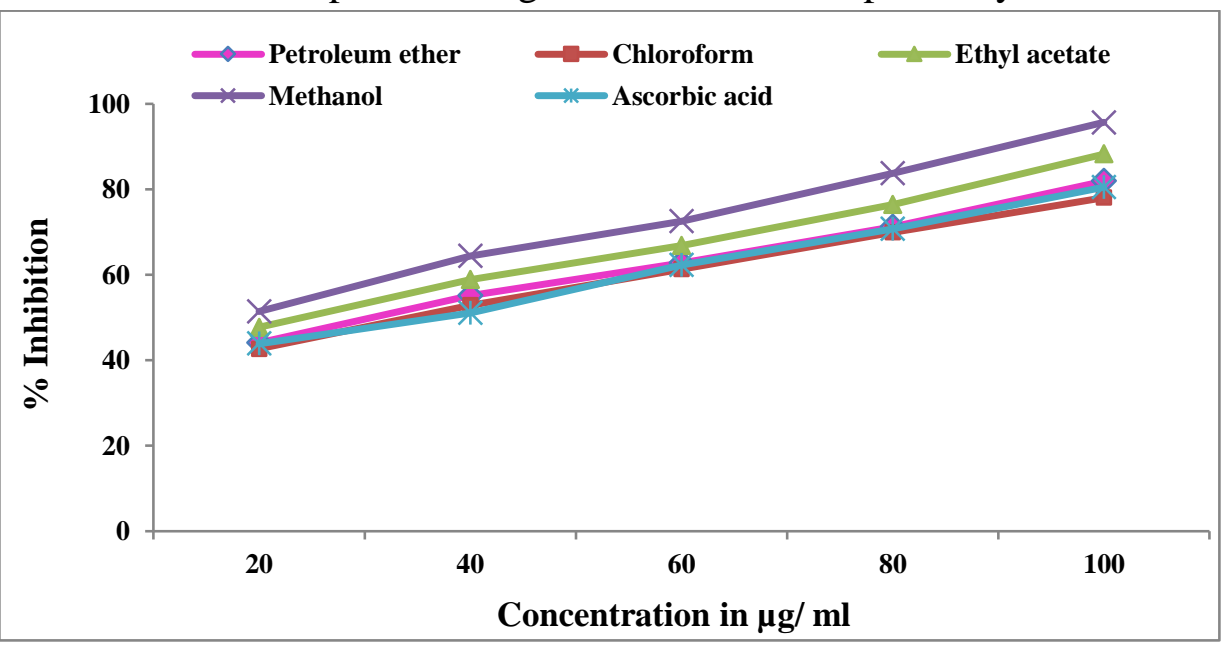

Figure 3. DPPH free radical scavenging activity of different extracts of A. graveolens and standard Ascorbic Acid at different concentrations.

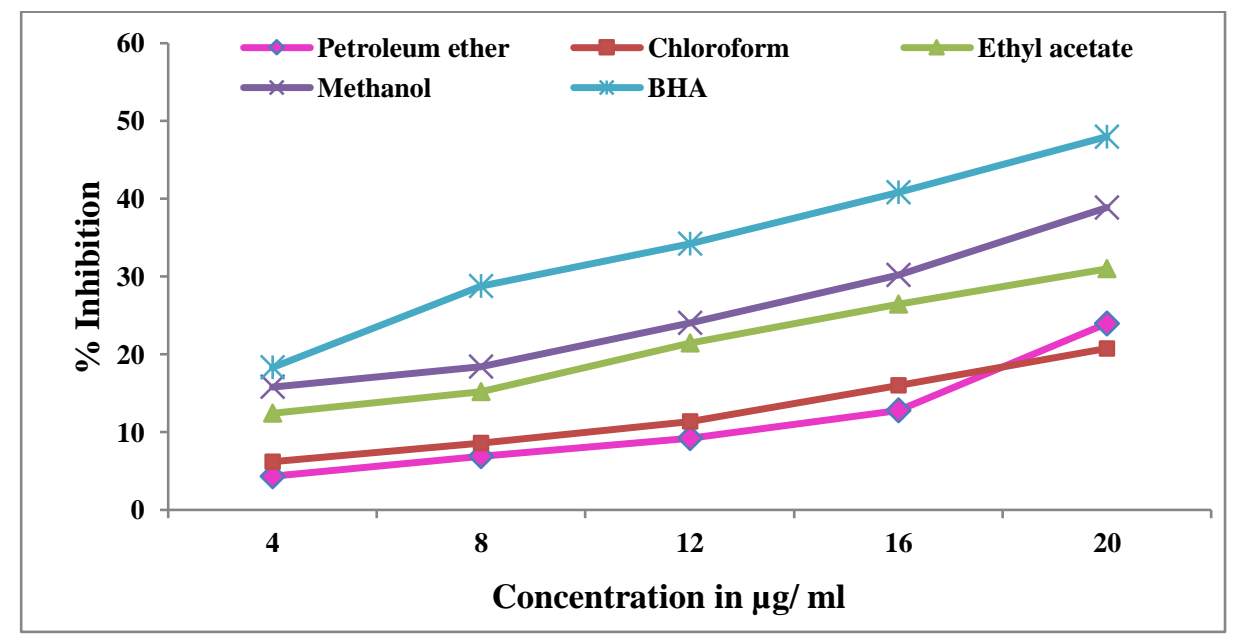

Figure 4. Hydroxyl radical scavenging activity of different extracts of A. graveolens and standard BHA at different concentrations. 


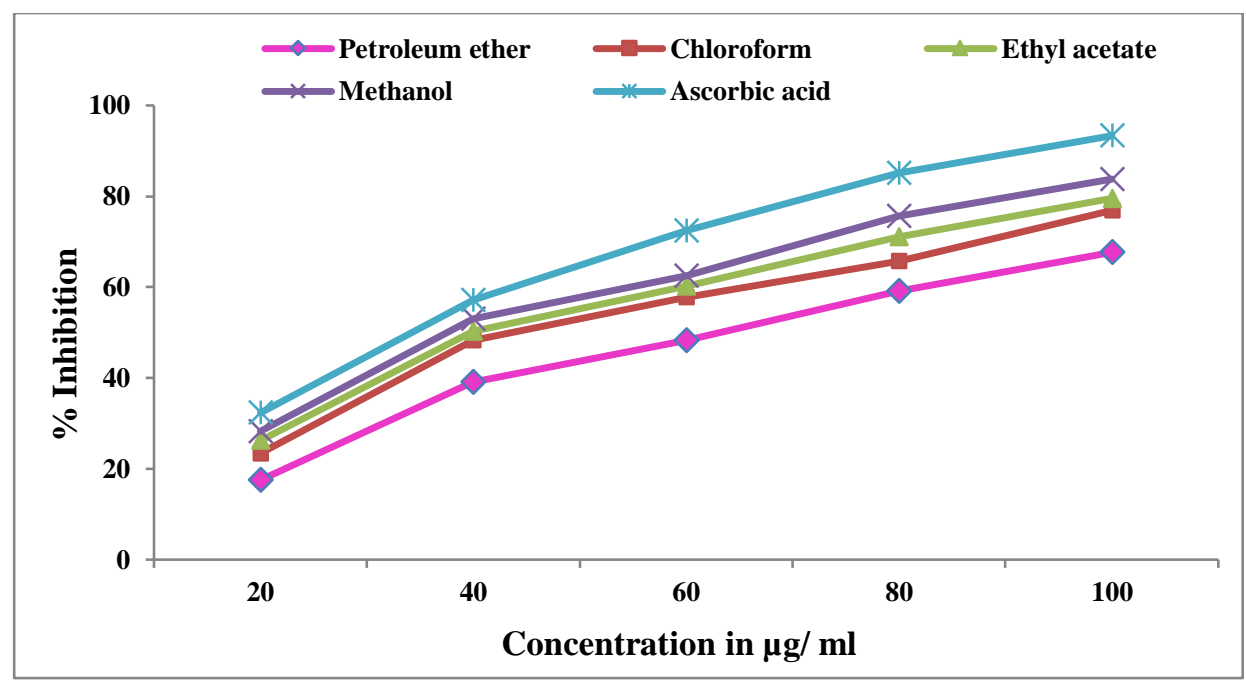

Figure 5. Scavenging effect of nitric oxide radical of different extracts of A. graveolens and standard AA at different concentrations.

\subsection{Phytochemical analysis.}

Phytochemical analysis of solvent extracts is presented in Table 6. Phenols, tannins, flavonoids, and proteins were present in methanol and ethyl acetate extracts. Methanol and petroleum ether extracts also contained steroids. Steriods and glycosides were present in all extracts.

Table 6. Phytochemical analysis of solvent extracts of A. graveolens.

\begin{tabular}{l|c|c|c|c}
\multirow{2}{*}{$\begin{array}{c}\text { Phytochemical } \\
\text { compounds }\end{array}$} & Petroleum ether & Chloroform & Ethyl acetate & Methanol \\
\cline { 2 - 5 } & - & - & - & - \\
\hline Alkaloids & - & - & + & + \\
\hline Flavonoids & - & - & + & + \\
\hline Terpenoids & - & - & + & + \\
\hline Tannins & + & + & + & + \\
\hline Steroids & + & + & - & - \\
\hline Glycosides & + & - & - & - \\
\hline Carbohydrates & - & - & - & -
\end{tabular}

\section{Discussion}

Many vital phytochemicals are obtained from various parts of the plants. Herbal remedies in traditional folk medicine are found to be a suitable alternative for the development of active new drugs for chemotherapy, which could overcome the growing problems of drug resistance and avoid the effects of the currently available antibiotics. The increasing interest in secondary metabolites and their medicinal properties has prompted to search for new compounds. Thus, the proposed work describes the cited considerations and the antibacterial and antioxidant activity of different solvent extracts of $A$. graveolens.

Remarkable antibacterial activities were obtained from all the extracts of A. graveolens against human pathogenic bacteria and good activity of 18-19 $\mathrm{mm}$ inhibition zone with methanol extract. The review found that the antibacterial activity of A. graveolens against human pathogenic bacteria from its essential oil, while crude soxhlet extracts activity was insignificant. But in the present study, methanol extract obtained by soxhlet extraction has 
recorded promising activity. Many researchers have demonstrated that the essential oil of $A$. graveolens showed a significant antibacterial activity [22-25]. The literature survey suggests that highly polar solvents such as acetone, ethanol, and methanol extracts possess potential activity, which has also been evident from the present investigation [26,27]. This suggests that most of the active compounds are extracted better by high polar solvents.

The $\mathrm{IC}_{50}$ values of $A$. graveolens showed that methanol extract was nearly potent than the standard in all three methods. All the extracts of the plant possessed a good scavenging ability when compared to the standard ascorbic acid. Antioxidant capacity of A. graveolens was studied by earlier workers with infusions and decoctions [27], Anethum oil [26], alcohol extracts [28,29], but most of the studies were on the essential oils, while in the present research, different soxhlet extracts of $A$. graveolens were subjected to antioxidant assay, and methanol extract followed by ethyl acetate and chloroform extracts were found to be potent antioxidants. The choice of solvent for extraction, maturity of the samples, and extraction techniques may have a profound effect on observed antioxidant content and capacity, resulting in variation in the scavenging efficacy of the extracts[30].

The antioxidant activity comprises free radical scavenging capacity, reducing ability, metal ion chelating ability, and inhibition of lipid peroxidation. DPPH was used as a substrate to evaluate the free radical scavenging activity of $A$. graveolens extracts. DPPH radical contains an odd electron responsible for the formation of the blue color [31]. When DPPH accepts an electron from the extract, it gets converted into colorless diphenyl-picryl hydrazine. The reduced DPPH could be quantified spectrophotometrically at $517 \mathrm{~nm}$. The methanol extract of the plant recorded the least value of $19 \mu \mathrm{g} / \mathrm{ml}$ followed by ethyl acetate $(21 \mu \mathrm{g} / \mathrm{ml})$, petroleum ether $(24 \mu \mathrm{g} / \mathrm{ml})$, and chloroform $(25 \mu \mathrm{g} / \mathrm{ml})$ extracts, indicating that all extracts have better scavenging activity as compared to ascorbic acid.

Hydrogen peroxide is a well-known oxidizing agent but, on few occasions be toxic to the host cell due to the hydroxyl radical. By oxidation of these thiol groups (-SH) it can inactivate few enzymes directly. The oxidation of $(-\mathrm{SH})$ groups by oxidants may thus lead to disruption of various cellular functions and even cell death [32]. The extracts have shown $\mathrm{H}_{2} \mathrm{O}_{2}$ decomposing activity at a lower concentration of $28,32,34,38,28 \mu \mathrm{g} / \mathrm{ml}$ of methanol, E. acetate, petroleum ether, and chloroform extracts, respectively slightly lesser than the standard BHA.

Nitric oxide is a potent pleiotropic mediator of the physiological process such as smooth muscle relaxant, neuro-signaling, platelet aggregation inhibition, and cell-mediated toxicity regulation. The NO reacts with superoxide and gives rise to various other reactive nitrogen species (RNS) such as $\mathrm{NO}_{2}, \mathrm{~N}_{2} \mathrm{O}_{4}$, and peroxynitrite, which attack and damage various cellular molecules[33]. Methanol extract showed scavenging activity at a concentration slightly higher than that of the standard by decreasing the amount of nitrite, which is toxic to the cell.

Similar results were observed in the antioxidant capacity of chloroform extract of $A$. graveolens where the extract recorded low phenol content and better antioxidant capacity when compared to other extracts. The correlation between total phenol content and antioxidant activity can be influenced by extraction procedures, assay methods, solvent, and variation in the nature of compounds. The antioxidant capacity of $A$. graveolens was studied by earlier workers with infusions and decoctions[26,27] Anethum oil, alcohol extracts [28,29]. However, most of the studies were on essential oils. Nonetheless, in the present research, different soxhlet extracts of A. graveolens were subjected to antioxidant assay. Methanol extract followed by ethyl acetate and chloroform extracts was found to possess potent antioxidant properties. The 
choice of solvent for extraction, maturity of the samples, and extraction techniques may have a profound effect on observed antioxidant content and capacity, which result in variation in the scavenging efficacy of the extracts[30]. The chemical complexity of extracts, often a mixture of compounds with different functional groups, polarity, and chemical behavior, could lead to scattered results depending on the test employed.

There are several methods for the determination of antioxidant activities. The chemical complexity of extracts, often a mixture of compounds with different functional groups, polarity, and chemical behavior, could lead to scattered results depending on the test employed. Therefore, an approach with multiple assays for evaluating the antioxidant potential is appropriate[34].

The review on antimicrobial activity suggests that activity is more in organic solvent extracts because the antimicrobial principle was either polar or non-polar. In the sequential extraction technique, the chemical constituents are partially separated according to their polarity, the least polar components extracted into low polar solvents and high polar components extracted into the higher polar solvents, which leads to progressive separations of the active compounds. This partial separation of active components may be an advantage to reduce the antagonistic effects of chemical constituents present in crude mixture may interfere with the action of the other[35]. This has been evident in the present investigation. The selected plant material was sequentially extracted in the current study with different solvents to increase polarity, which plays an important role in the interaction of natural products, which influences the antibacterial activity.

The study on crude extracts is advantageous to additive or synergetic effects of the mixture, resulting in an increased antimicrobial spectrum of the extract and decreased risk of pathogen resistance to a mixture of active compounds[36]. The activity of all the extracts of selected plants was tested by employing both agar cup and disc diffusion methods. The inhibition zone was higher in the cup diffusion method in all the studied plant extracts when compared with the disc diffusion method, which may be due to the maximum diffusion of the extracts into the media, leading to the spread of the phytochemical or active compounds of the extracts to a wider diameter resulting in higher inhibition zone [37].

\section{Conclusions}

In conclusion, plant extracts rich in secondary metabolites are quite safe, and their toxicity is not a problem of concern, unlike those of BHA and synthetic drugs. Methanol extracts of A. graveolens possess a broad spectrum of activity against several human pathogenic and potent antioxidant properties. A natural substance obtained from plants, a part of a daily diet being a nutritional supplement with antimicrobial and antioxidant properties, constitutes a new source of herbal drugs.

\section{Funding}

The research did not receive any funds from any source

\section{Acknowledgments}

One of the authors B. Jayalakshmi is thankful to the University Grants Commission, New Delhi, for awarding FIP-Teacher Fellowship and the Department of Collegiate Education, 
Govt. of Karnataka, Bangalore, and also the University of Mysore, Mysuru for providing the laboratory facilities.

\section{Conflicts of Interest}

The authors declare no conflict of interest.

\section{References}

1. World Health Report, Geneva,Switzerland . 2003, 1-50.

2. Ragunath, D. Emerging antibiotic resistance in bacteria with special reference to India. Journal of Bioscience 2008, 33, 593-603, https://doi.org/10.1007/s12038-008-0077-9.

3. Okorie N.H.; Mbah, C.J.; Orabueze, I. "Antioxidants Properties of Natural and Synthetic Chemical Compounds: Therapeutic Effects on Biological System". Acta Scientific Pharmaceutical Sciences 2019, 3, 28-42, https://doi.org/10.31080/ASPS.2019.03.0273.

4. Salehi, B.; Martorell, M.;Arbiser, J.L.;Sureda, A.; Martins, N.; Maurya, P.K.; Sharifi-Rad, M.; Kumar, P.; Sharifi-Rad, J. Antioxidants: Positive or Negative Actors? Biomolecules, 2018, 8, 124, https://doi.org/10.3390/biom8040124.

5. Ashraf, M.A.; Iqbal, M.; Rasheed, R.; Hussain, I.; Riaz, M.; Arif, M.S. Environmental stress and secondary metabolites in plants: an overview. In Plant metabolites and regulation under environmental stress. AcademicPress 2018, 153-167, https://doi.org/10.1016/B978-0-12-812689-9.00008-X.

6. Zandalinas, S.I.; Mittler, R.; Balfagón, D.; Arbona, V.; Gómez-Cadenas, A.; Plant adaptations to the combination of drought and high temperatures. Physiologia Plantarum, 2017, 12540. https://doi.org/10.1111/ppl.12540.

7. Jain, C.; Khatana, S.; Vijayvergia, R. Bioactivity of secondary metabolites ofvarious plants: a review. International Journal of Pharmaceutical Science and Research, 2019, 2, 345-356, https://doi.org/10.13040/IJPSR.0975-8232.10(2).494-04.

8. Keo, S.; Leang, S.; Ny, C.; Lim, S.; KosalvorlakChean, Ung, H.; Maneenet, J.; Chulikhit, Y.; Chea1, S. Phytochemical Analysis and Antioxidant Property of Selected Medicinal Plants Native to Cambodia. Drug Designing \& Intellectual Properties International Journal. 2018, 1 , https://doi.org/10.32474/DDIPIJ.2018.01.000109.

9. Kamaraj, C.; Rahman, A.A.; Siva, C.; Iyappan, M.; Keerthy, A.V. Evaluation of antibacterial activity of selected medicinal plant extracts from south India against human pathogens. Asian Pacific Journal of Tropical Disease 2012, 2: S296-S301, https://doi.org/10.1016/S2222-1808(12)60169-8.

10. Begum, P.; Noman, M.A.; Abib, M.; Ahsan, M.; Islam, S.N. Antibacterial activity of ethnic vegetables consumed by the indigenous people living in Chittagong hill tracts. European journal of medicinal plants 2017,18, 1-7, https://doi.org/10.9734/EJMP/2017/32059.

11. Wealth of India, Vol.III, NISCAIR, New Delhi, 2005, 27-28.

12. Jana, S.; Shekhawat, G.S. Anethum graveolens: An Indian traditional medicinal herb and spice. Pharmacognosy Review 2010, 4, 179-184, https://doi.org/10.4103/0973-7847.70915.

13. Udayan, P.S.; Balachandran I. Medicinal plants of Arya Vaidya Sala Herbal Garden, Araya Vaidya Sala, Kottakkal. 2009, 522.

14. Perez, C.; Pauli, M.; Bazerque, P. An antibiotic assay by agar well diffusion method. Acta Bio Med Exp , 1990, 15, 113-115.

15. National Committee for clinical Laboratory standards, Performance standards for Susceptibility Testing; Twenty-fifth International Supplement, M100-S12 ( $\left.\mathrm{M}_{2}\right)$ NCCLS Wayne.

16. Das, K.; Tiwari, R.K.S.; Shrivastava, D.K. Techniques for evauation of medicinal plant products as antimicrobial agent: Current methods and future trends. Journal of Medicinal Plants Research, 2010 , 4, 104-111.

17. Qaiyami S. Macro and Microdilution methods of antimicrobial susceptibility Testing. In: Schwalbe R, SteeleMoore L, Goodwin AC editors. Antimicrobial Susceptibility Testing Protocols. New York, Taylor \& Francis Group 2007; p.75-81.

18. Blois M.S. Antioxidant determinations by the use of a stable free radical. Nature, 1958, 181, 1199-1200, https://doi.org/10.1038/1811199a0. 
19. Ruch, R.J.; Cheng, S.J.; Klaunig, J.E. Prevention of cytotoxicity and inhibition of intercellular communication by antioxidant catechins isolated from Chinese green tea. Carcinogenesis 1989, 10, 10031008, https://doi.org/10.1093/carcin/10.6.1003.

20. Green, L.C.; Wagner, D.A.; Glogowski, J.; Skipper, P.L.; Wishnok, J.K.; Tannenbaum, S.R. Analysis of nitrate, nitrite and $\left[{ }^{15} \mathrm{~N}\right]$ nitrate in biological fluids. Anal Biochem., 1982, 126, 131-138. https://doi.org/10.1016/0003-2697(82)90118-x.

21. Harborne, J.B. Phytochemical Methods, Chapman and Hall Publications, London, 7-8 1998. https://doi.org/10.1007/978-94-009-5570-7_1.

22. Singh, G.; Kapoor, I.P.S.; Pandey, S.K.; Singh, U.K.; Singh, R.K. Studies on essential oils: Part 10; Antibacterial activity of volatile oils of some spices. Phytotherapy Research, 2002, 16, 680-682, https://doi.org/10.1002/ptr.951.

23. Stavri, M.; Gibbons, S. The antimycobacterial constituents of Dill (Anethum graveolens). Phytotherapy Research, 2005, 19, 938-941, https://doi.org/10.1002/ptr.1758.

24. Kaur, G.J.; Arora, D.S. Antibacterial and phytochemical screening of Anethum graveolens, Foeniculum vulgare and Trachyspermum ammi. BMC Complementary and Alternative Medicine, 2009, 9, 30, https://doi.org/10.1186/1472-6882-9-30.

25. Mahmoodi, A.; Roomiani, L.; Soltani, M. Chemical composition and antibacterial activity of essential oils and extracts from Rosmarinus officinalis, Zataria multiflora, Anethum graveolens and Eucalyptus globuleus. Global Veterinaria, 2012, 9, 73-79.

26. Singh, G.; Maurya, S.; de Lampasona, M.P.; Catalan, C. Chemical constituents, antimicrobial investigations and antioxidative potentials of Anethum graveolens L. essential oil and acetone extract. Journal of Food Science, 2005, 70, 208-215, https://doi.org/10.1111/j.1365-2621.2005.tb07190.x.

27. Albayrak, S.; Aksoy, A.; Sagdic, O.; Albayrak, S. Antioxidant and antimicrobial activities of different extracts of some medicinal herbs consumed as tea and spices in Turkey. Journal of Food Biochemistry, 2012, 36, 547-554, https://doi.org/10.1111/j.1745-4514.2011.00568.x.

28. Shyu, Y.S.; Lin, J.T.; Chang, Y.T.; Chiang, C.J.; Yang, D.J. Evaluation of antioxidant ability of ethanolic extract from dill (Anethum graveolens L.) flower. Food Chemistry, 2009, 115, 515-52, https://doi.org/10.1016/j.foodchem.2008.12.039.

29. Popa, C.V., Lungu, L., Savoiu, M., Bradu, C., Dinoiu.V.; Danet, A.F. Total antioxidant activity and phenols and flavonoids content of several plant extracts. International Journal of Food Properties, 2013, 15, 691701, https://doi.org/10.1080/10942912.2010.498545.

30. Szeto, Y.T., Tomlinson, B.; Benzie, I.F.F., Total antioxidant and ascorbic acid content of fresh fruits and vegetables: Implications for dietary planning and food preservation. British Journal of Nutrition, 2002, 87, 55-59, https://doi.org/10.1079/BJN2001483.

31. Sharma, A.; Bhardwaj, S.; Mann, A.S.; Jain, A.; Kharya, M.D. Screening methods of antioxidant activity: an overeview. Pharmacognosy Reviews, 2007, 1, 232-238.

32. Martinez, G.; Giuliani, A.; Leon, O.S.; Perez, G.; Nunez, S.A.J. Effect of Mangifera indica L. extract on protein and hepatic microsome peroxidation. Phytother Res., 2001; 15, 581-585. https://doi.org/10.1002/ptr.980.

33. Pardini R.S. Toxicity of oxygen from naturally occurring redox active pro-oxidants. Arch Insect Biochem Physiol., 1995; 29, 101-118, https://doi.org/10.1002/arch.940290203.

34. Karadag, A.; Ozcelik, B.; Saner, S. Review of methods to determine antioxidant capacities. Food Analytical, 2009, 2, 41-60, https://doi.org/10.1007/s12161-008-9067-7.

35. Boncan, D.A.T; Tsang, S.S.K; Li, C.; Lee, I.H.T.; Lam, H.M.; Chan, T.F.; Hui, J.H.L. Terpenes and Terpenoids in Plants: Interactions with Environment and Insects. International Journal of Molecular Sciences, 2020, 21, 7382, https://doi.org/10.3390/ijms21197382.

36. Naikoo M.I., Dar M.I., Raghib F., Jaleel H., Ahmad B., Raina A., Khan F.A. Naushin F. Role and regulation of plants phenolics in abiotic stress tolerance: an overview. In Plant signaling molecules. Woodhead Publishing, 2019; 157-168, https://doi.org/10.1016/B978-0-12-816451-8.00009-5.

37. Valgas, C.; de Souza, S.M.; Smania, E.F.A.; Smania, A. Jr. Screening methods to determine antibacterial activity of natural products. Brazilian Journal of Microbiology, 2007, 38, 369-380, https://doi.org/10.1590/S1517-83822007000200034. 